\title{
Tourism and its Role in Environmental Conservation
}

\author{
Anup K.C. \\ Department of Environmental Science \\ Amrit Campus, Tribhuvan University, Kathmandu, Nepal \\ kcanup04@gmail.com
}

\begin{abstract}
Ecotourism is a form of tourism which supports biodiversity conservation, socio-cultural development and economic enhancement of a country. It had positive as well as negative impacts on environmental, social and economic aspects of the environment. In the context of Nepal, ecotourism had supported conservation of flora and fauna, livelihood of poor and needy people and development of culture and society. Researchers have used direct observation, questionnaire surveys, focus group discussions and key informant interviews to collect the primary data and different published documents, journals and books for collecting secondary data on ecotourism issues. Also, they have used different analytical techniques based on tabular representation, graphical presentations and statistical methods. Ecotourism had helped to increase the source of revenue which in turn had supported environmental conservation activities. In many areas of the world, floral and faunal diversity had increased significantly by the initiation of ecotourism programs. Dependent people on natural resources, park beneficiaries and park conservators are directly supplemented by the earning received from the ecotourism activities. It has led to disappearance of respect, culture and traditions in some cases while it had also encouraged showing their costumes, songs, dances and other social features in other cases. For long term development of ecotourism, small scale tourism based on community should be focused rather than a large scale mass tourism.
\end{abstract}

Keywords: Ecotourism, environmental conservation, methodological issues, socioeconomic development

\section{Introduction}

Tourism is a sector which focuses on travelling from one place to other, spending time outside of a hometown, moving to a new place with an intention of economic activity, spending leisure time, and involving in other extra activities. In the countries 
where tourism is the main sector, it is contributing a lot for providing sustainable living of the people (K C, 2017a). Ecotourism is a form of tourism which supports all three aspects of sustainable development; particularly conservation of biological diversity, reduction of poverty, and opportunities of business. It can contribute towards conservation of environment and development of society and economy of a nation and the whole world (K C, 2017c).

Ecotourism projects are using renewable energy extracted from sun, wind, water and biomass. Income from ecotourism is encouraging them to use these resources and in turn helping to attract more tourists and increase the source of revenue. Hospitality sector in ecotourism projects had also set up important guideline for running their projects sustainably, increase their environment good will and increase excellence and popularity of their tourism business. Hydroelectricity is used for lighting, warming the water, cooking food, cooling things, saving food items, warming the space, water circulation in home and in other electrical appliances. Also, electricity is useful for washing clothes and dishes, using dryers and air filters, preparing toasts and food items, watching televisions and using mobile phones and televisions. Use of these electrical items is helping to save energy and preserve the environment (K C, 2016).

It is much better to apply theory of sustainable development to utilize the nature and the culture. If an ecotourism project is to be developed in rural area, it should not harm the nature, culture and society of the area instead it should prioritize increase in standard of living and enhancement of the local economy. A new form of ecotourism (rural or village tourism) helps visitors to receive benefits from scenic beauty, cultures, traditions, and rituals of a country (Regmi, 2016).

\section{Biodiversity}

Biological diversity or biodiversity is sum total of all the living things combining their outer nature and their functions from their genes, species and ecosystems. It provides various ecosystem services useful to the mankind in which tourism benefits is one of the important one. There are various positive and negative situations regarding the current floral and faunal diversity (K C \& Ghimire, 2015; K C, Joshi, \& Aryal, 2014). Biodiversity is high in low income countries but conflicts of its conservation and poverty, is a challenging task which need to be resolved on time. There should be focus on biodiversity protection in these low income countries of the tropical region whose harvest rate is low. In the place with more population, there are few isolated patches, which are rich in biological diversity, with the occurrence of endemic species. Similarly, the places with less population also contain high diversity of floral and faunal species (Mellor, 2002). 


\section{Ecotourism}

Tourism has impact on local resources, income, local behaviors and development works. In the context of whole world, mountain climbing and walking in a trekking route are some ecotourism programs in mountainous areas which help to enhance the living standard of people. It is the nature of visitors to spend their leisure time in high elevations for mountain climbing and walking in a well-defined route, spending time in ocean beach for entertainment and observing the variety of plants and animals around it (K C, 2017a). Different forms of ecotourism are green tourism, community managed tourism, sustainable tourism whose main aim is floral and faunal diversity conservation (Brandon \& Margoluis, 1996).

Even the cultural heritage and old buildings of Europe and other important destinations are attracting more international tourists which are often enhanced by constructed infrastructure such as swimming ponds. In few countries, attractive wildlife and natural flora are alluring nature lovers that are also supported by boating and other water games. In Caribbean, natural resources of coast such as palm trees and corals, and enjoyment in beaches full of sand with cleaning opportunities, swimming, skiing, diving and sunbathing is attracting more foreigners. In the case of southern and Central American counterparts; evergreen forest, protected areas, natural scenic beauty, viewing birds and wildlife, natural hikes, climbing, and landscapes of volcano is alluring more visitors (Bovarnick, Alpizar, \& Schnell, 2010). Currently, ecotourism covers up to about twenty percent of all international visitors which is increasing at an annual rate of $10 \%$ to $30 \%$. Hundreds of billions of US dollar is generated from this sector which is an important economic source of many people (Casey, Vickerman, Hummon, \& Taylor, 2006).

The need of high elevation tourism for average economic standard people will be high due to the rise in heat of the urban area and the low elevation as a result of climate change. It will increase alternative options for the mountain region to invest more on the sustainable tourism sector to harvest more unused resources, earn financial incentives and sustain the local livelihood options. It is not easier to provide direct benefits to mountain people but this sector should be tie up with other programs to decrease the poverty level and help towards long term development of the people. For this purpose, long-term high altitude tourism need to be combined with a broad insight and similar understanding of concepts, ideas and plans in the local context (Kruk, 2009).

\section{Ecotourism in Nepal}

Least developed countries, like Nepal, are benefitted a lot from ecotourism projects which promote their environment, economy and society holistically (K C, 2017c). Travellers coming from inside as well as outside of a country move to the 
mountainous area for trekking and mountain climbing in Nepal. There is a high chance of getting information about local culture, observing the interesting view of different mountain ranges, and enjoying different types of natural resources ( $\mathrm{K}$ C, 2017a). Different areas of Nepal are developed as a site of ecotourism from east to west and from north to south. Different villages inside Annapurna conservation area, Manaslu conservation area, Kanchenjunga conservation area, Gaurishankar conservation area, Langtang national park, Chitwan national park, Panchase region, Illam, Syangja, Kathmandu, and many other districts are developed as important sites for tourism promotion in Nepal.

\section{Ecotourism and biodiversity conservation}

Ecotourism is an important strategy which helps in cultural heritage management, environmental conservation, social and economic development of local as well as national level. Tourists travelling in any area supplement financial benefits which help in conservation activities as well as overall development of the place. The ultimate objective of ecotourism is environmental management so these projects are designed, observed and checked keeping these objectives in forefront. To prepare baseline for successful implementation of ecotourism projects in environmental conservation, five different advantages to floral and faunal diversity preservation are set up. There is a need of proper design for assessing the inter relationship among conservation and project based activities in local and national level (Brandon \& Margoluis, 1996). In the case of Nepal, community forest helps in floral and faunal diversity conservation which in turn helps in attracting national and international visitors. Increase in number and type of plant species and appearance of more animal species nearby the forest can increase the scope of tourism in long run (K C, 2017b).

\section{Methodological issues}

In this part, different methodologies applied by researchers in ecotourism issue were reviewed and documented as follows:

With an aim to observe the interrelation of environmental resource and tourism in Shey Phoksundo National Park of Nepal, Varsi (2012) reviewed both the beneficial and adverse effects on nature from tourism sector.

With an aim to assess the role of ecotourism on livelihood enhancement and biological diversity conservation, Nyaupane \& Poudel (2011) conducted a study in Chitwan National Park (CNP) of central Nepal. They started their research with the help of literature review focusing on relationship between tourism, livelihood, conservation and tourism development. They also used appreciative inquiry (AI) approach in the month of December 2008 and January 2009 with the support of park staffs to 3 different communities inside buffer zone. They were selected on the basis of tourism development; primarily infrastructures for tourists and presence 
of tourists in the area and were categorized as most developed, medium level and least developed stages. This AI method is an investigation tool to assess the relation between conservation of biological diversity, enhancement of tourism and livelihood. The AI steps were four dimensional which includes five different steps. The first phase was grounding that was also called inception phase, which includes, rapport building, determining stakeholders, choosing participants, and briefing of investigation techniques. The selected respondents were governmental staffs, local residents, NGOs, CBOs and tourism business owners.

With an objective to assess the difference in valuation done by tourists and their willingness to pay for the management and services for the recreational activities, Kaffashi et al., (2015) conducted a study in Penang national park of Malaysia. They used structural equation modeling (SEM) and choice experiment (CE) as a method to assess preferences and willingness to pay of visitors for the development of national park in the future. To measure the complex dimensions of park preservation and tourist's means of entertainment, CE method was implemented. For this purpose, they used different parameters such as; ecosystem management, techniques for recreation, mediums for delivering information, and entry fee.

With an objective to assess the relationship between ecotourism and biological diversity conservation, Makindi, (2016) conducted a study in Kimana Community Wildlife Sanctuary of Kenya. It was located on communal land owned by Kimana Maasai of Kenya. As the wildlife sanctuary was managed by the community, information related to the research was gathered from local people at the household level with the help of one hundred questionnaire surveys.

$\mathrm{K} C$ et al (2015) had completed their research on ecotourism in Ghandruk area of Annapurna region with the help of field investigation, 242 questionnaire surveys, 3 focus group discussions and 5 key informant surveys. They have identified impacts of tourism on ecological management, socio-cultural resource protection, and economic and livelihood enhancement.

K C and Thapa Parajuli (2014b) had done their research on tourism and livelihood around trekking routes of Manaslu region of Gorkha district of Nepal. For collecting primary information of this purpose, they have conducted 66 questionnaire surveys, 3 focus group discussions and 5 key informant surveys to the tourism dependent and non-dependent families. The analysis of data was done with the help of graphical, regression and correlation analysis.

The compilation of publications and researches by Kruk, (2009) provide a broad range of high altitude tourism enhancement ideas, plans and concepts which are proven applicable in day to day life for long term benefits of poor, rural and mountain people. In the case of Nepal, few tourism projects have been initiated and 
reviewed which helped in the development of local area with the support of adjoining countries.

With an aim to identify the role of protected area and its tourism activities on the local communities nearby it, Lipton and Bhattarai, (2014) conducted a study in Chitwan National Park to assess the role of its tourism to Tharu communities of Sauraha and Chitwan district. The responses of local Tharu residents on social, economic and cultural aspects of their life were taken for this study.

K C, (2016) had prepared a review paper on ecotourism by assessing different published and non-published documents around the world. He had observed that researchers working on ecotourism have applied different techniques for assessing the impacts of this sector on different aspects of the society.

With an objective to identify the data on tourism enhancement in rural area of Nepal, Regmi, (2016) conducted a questionnaire survey to the well-defined members of rural regions of Nepal.

Mbaiwa and Kolawole, (2013) reviewed various publication related to ecotourism researches throughout the world which shows mixed results of tourism welfare.

Hussain et al, (2012) conducted a study to assess the inter relationship of tourism and livelihood in Kaziranga area of north eastern part of India. They observed different aspects of tourism revenue and its leakages to assess impacts on environmental management. For this purpose, they have collected primary as well as secondary data of tourism and living standard of the people. The information from published data of Kaziranga implementation plan, data of tourism agency of Assam, local taxi association, self-help group, and NGOs were collected for this study. To collect first hand data, questionnaire survey was carried out in 2006 and 2007 to the service providers of construction related activities, accommodation and fooding facilities and grocery shops. Questionnaire surveys were carried out by using stratified random sampling by contacting 138 visitors directly and indirectly. Also 60 surveys were carried out randomly to visitors which represent a total of $15 \%$ of all visitors travelling to the national park to find out the expenditure incurred during their stay at Kaziranga national park. Also group interaction was carried with park managers, local people, and tourism facilities operators with the help of structured questionnaires.

Wrobel and Kozlowski, (2011) had conducted a study in Annapurna conservation area of western Nepal with the help of questionnaire surveys and direct interviews to assess the willingness to pay of participants towards fee to enter inside the conservation area. The analysis of data was done using various statistical tools from statistical package for social sciences software. 
K C and Thapa Parajuli, (2014a) had assessed the impact on climate change on tourism sector in Manaslu region of Nepal with the help of household surveys, key informant interviews and focus group discussions. They have assessed both the primary as well as secondary data related to climate change and tourism in that case and have analyzed the information by using statistical analysis tools.

\section{Analysis and Discussion}

\section{Beneficial aspects of ecotourism}

Ecotourism had both the beneficial and adverse impacts on environment, society and economy of a nation. As compared to the adverse impacts, beneficial aspects are always at higher level which is helping the all-round development of society, nation and the whole globe. To increase the beneficial aspects, cooperation between different stakeholders, skill development trainings and appropriate management policy for long term operation of these projects is essential. In the case of Nepal and the globe, ecotourism support environment conservation activities, job opportunities, improving living standard, and promotion of culture and traditions (K. C., 2016). There were 3 main effects of ecotourism for long term enhancement of the local area, mainly on economy, society and culture, and the environment. Tourism can be further enhanced and managed with the help of public involvement, knowledge dissemination about food and hygiene, and preservation of environment (Regmi, 2016).

Wrobel and Kozlowski (2011) observed that around two-third of the participants have expenditure less than five thousand dollars in a year for 5 years period while more than one-third have expenditure higher than five thousand dollars in a year. A total of $71.3 \%$ visitors have already paid money as an entrance fee in other protected area before coming to Annapurna area. As most of the visitors had come to the area for trekking purpose so around one-third of them had rented a tourist guide for this case. About $92 \%$ visitors have rated their best feelings to be there in the conservation area and more than $73 \%$ of them had rated the situation of environment as more than average. On an average, tourists have spent more than 15 days inside Annapurna conservation area and they have spent more than 20 dollars in a day during their visit.

If the tourism is centered in a community, there is a strong relationship between tourist and the local organizers and it also support both the financial and environmental protection benefits. Nature and its resources are the important source of enticing foreign visitors in most of the states with rising economies. With a purpose of attaining social, natural and sustainable principles, community centered tourism is one of the well renowned form of ecotourism which targets enhancement of a country with environmental protection objectives. It also includes management of nature, culture, 
flora, fauna, water, forest, landform, and other important heritage. To attain long term environmental and developmental advantages, the interrelationship of various environmental resources should be maintained properly. For attaining this, there should be proper interaction between state managers, forest preservers, authorities of protected areas, tourism stakeholders, economic partners, farmers, and the policy makers in the global arena. If there is proper interaction of various stakeholders, state owned and other group owned resources can be utilized for running a tourism business. Even the private businesses involved in tourism can use local resources, services and products necessary for supporting their visitors (TMI, 2000).

\section{Adverse effects of tourism}

There are some adverse impacts on the ecosystem in spite of conducting sensitization programs and activities for the preservation of nature (Regmi, 2016). Due to the flow of profit from tourism business to urban area, there exist power imbalance between rich people of town area and the local people. It can be also observed that majority of profit reaches the hand of rich people of town area and the tourist entrepreneurs. As the main idea of eco-tourism projects is to support the economic standard and livelihood of poor local people, in some cases, there are more benefits for tour operators and less to the local people (Varsi, 2012).

\section{Beneficial effects of tourism on biodiversity}

Different behavioral rules and regulations are set up for tourists inside a national park to minimize the adverse impacts on environmental resources (Varsi, 2012). Most of the ecotourism projects attain objectives of environmental conservation and sustainable development (Narain \& Orfei, 2012). The earning from tourism activities should be beneficial in such a way to bring changes in their consumption pattern. Also, tourist destination should be attractive enough to produce adequate financial resources and provide incentives for poor people to reduce the use of their environmental resources and support in conservation activities. It is helpful if the tourism business is developed properly with the presence of attractive faunal species. Also, there should be investment on infrastructure and training to enhance local people involvement and make tourism business profitable (Narain \& Orfei, 2012).

Nyaupane and Poudel, (2011) observed that local residents uses resource inside the park for timber, firewood, food for cattle, roofing materials, and other forest resources. Also, different food items, primarily seasonal fruits, fishes, mushrooms, seeds, bulbs, reeds, berries, and nuts were derived from the park. The main themes that relate enhancement of tourism, conservation of biological diversity, and enhancement of livelihood were economic incentives, conservation of biological diversity and ecosystem services, infrastructural development, building of capacity and empowerment. Local people empowerment can be generated from development 
of tourism and conservation of biological diversity. For attaining these benefits, Nepalese policy makers had delineated buffer zones to conserve rare plants and animals, enhance the living standard of residents, and minimize the conflict associated with people and the parks. Opportunity of knowledge to the residents could be generated through enhancement of tourism and conservation of biological diversity which also supports in enhancing society and politics.

The conservation agencies and institutions disseminate data related to tourism and preservation activities through various means, such as, information booklets, papers and maps. Apart from these, different learning opportunities are provided to local people around CNP to enhance their ecotourism business, guide tourists, produce incomes, improve their skills, improve leadership skills and preserve biological diversity. National parks are set up with a main objective to conserve floral and faunal diversity. They also support different programs to involve people in biological diversity protection, preservation of forests inside buffer zone, awareness generation, and reduction of pressure in biological resources. Attractive animals and their interesting behaviors are the main source of visitor's attractions in CNP. The national park promotes ecotourism activities, such as, watching wild animals, observing avifaunal species, boating in the river, adventurous activities in the water, and travelling in elephants (Nyaupane \& Poudel, 2011).

Apart from these, national parks also benefits people from non-monetary services, such as, fresh drinking water, clean air, fertile soil, water bodies, and free space. Also green energy technologies established in tourism businesses, such as biogas, reduces the health and sanitation costs, and save the firewood as well as its harvesting time. Parks also set up fencing systems which helps in the protection of floral diversity as well as agricultural production from wild animals. Fences connected with electricity and barbered wires, fences with mesh-wire and fences made up of bamboo, Jatropha and other plants are some of the common type of fences used in the current days to increase agricultural productivity, reduce encroaching on forests and public lands. By seeing these multiple benefits, park regulators should implement ecotourism as a major tool for enhancing livelihood and conserving biological diversity. It not only helps in providing information and amenities but also increases awareness and information related to tourism. It had helped in preservation of plants and animals, reduction in the use of environmental resources and promotion of biological diversity protection. On the other hand, if floral and faunal diversity is conserved and environmental resources are managed; it will increase number of visitors, increase the income and provide further economic incentives for environmental conservation (Nyaupane \& Poudel, 2011).

It was observed that implementation of entry fee makes the park exclusive for visitors, reduce their number, determine the purpose of visit, and generate revenue 
from them. Higher income from these fees would provide opportunity for expenditure in awareness generation, training for the securities, new investigations inside the park, increase in protection activities and reduction of ecosystem related problems inside Penang national park. To involve tourists in sustainable environmental friendly behaviors, special programs need to be designed by park officials. It will also help them to be an active member instead of just being passive to manage the resource and their own behavior. Visitors also prefer improvement in ecological services and like the good condition of environment as compared to the current situation. They prefer conservation of floral and faunal diversity and other environmental resources, increase in use values of resources, good health and sanitation facilities, and proper solid waste management practices. Tourists want to pay a high price for the improvements of basic recreational facilities and data provided to them about the park. It will support them to get idea about importance of ecosystem of these areas, manage the interrelationships between floral and faunal species of the nature, sustain the views of tourists, enlighten them about observing and feeling, support them in reducing adverse environmental impacts, and enhance activities for the management of environment. In this way, active involvement of tourists for maintaining the ecosystem and ecological resources will not only support tourist facilities but also maintain the quality of environment, biological diversity, ecosystem functioning and other ecological aspects (Kaffashi, et al., 2015).

Utilization of environmental resources and decrease in environmental services had demanded new and alternative form of tourism facilities which could replace traditional practices and models. Visitors mainly demand two major types of resources: natural and artificial resources of tourism industry (Bovarnick, et al., 2010).

For sustaining the tourism industry, tourism businesses have linked floral and faunal diversity, and ecosystem services and its maintenance into their everyday planning process. Even the travel agents started identifying benefits of arranging their economy to reduce adverse impacts and identify techniques to conserve and sustain the infrastructural construction and management. They also sustain the local culture and biological resources of a place where visitors enjoy, enhance quality of products they provide and enhance their business prestige, and maintain their income sustainably (Bovarnick, et al., 2010).

Ecotourism approach in the private sector is important in United States which offers important financial incentives for private landlords to manage and protect shelter and food of wild animals. Data related to ecological efficiency from income generated from tourism in US is very less. But, sustainable approaches such as Eco labeling for private sector can help to utilize ecologically sustainable approaches. Providing awareness to the users about ecological benefits of certain products and its system could help to enhance economic value for biological diversity and habitat 
protection. Eco labeling promotes the wellness of an individual as well as the whole community which had also recently initiated the important behaviors for the welfare of wild animals. These types of environmental friendly sustainable approaches allure large number of sensitive user and as a whole enhance the market economy (Casey, et al., 2006).

Local people had a feeling that establishment of this wildlife sanctuary had generated many options and had caused positive impacts on floral and faunal diversity. As there were no obstacles made in the boundary of the area, there was clear relationship between local people and the protected area. Also, there was very less conflicts of human and the wild animals leading to proper protection of wild animal's habitat. Infrastructural construction related to shelter, water, livestock, health, and education near the area was also helped by managers of the wildlife sanctuary. After assessing the data and the results, it was observed that local people have good response on nature based tourism and floral and faunal diversity conservation in the protected area of Kimana. Biological diversity management had supported tourism and tourism had supported the income and livelihood of local people around the protected area (Makindi, 2016).

Also, native people believe that tourism had beneficial impacts on conserving environmental resources, and floral and faunal diversity in long-term. It also helps in rural development in social and ecological context. The traditional methods of conservation were inclined centrally, follow new cultures, western styles, and were generally top-down which eliminates local people of developing economies in making important decisions for environmental resource management. But, conservation inclined to community focuses on environmental resources conservation, floral and faunal conservation, and tourism development in the long run (Mbaiwa \& Kolawole, 2013).

In other case, tourism supports non-use and long term use of environmental resources which is identified by researchers, park officials, people depending on forests and local residents. But example of Kaziranga national park shows that income generated from tourism is not equally divided to the beneficiaries and it is unable to support in floral and faunal diversity conservation. It is supposed to lose financial benefits, decrease in flora and fauna, and exploitation of working people. To enhance the living standard of native people and to help in protection of the park, local park authority need to be uplifted and native communities need to be strengthened to contest with other tourism stakeholders (Hussain, et al., 2012).

There is positive interrelationship between tourism and biological environment in most of the cases but some large scale tourism near sea and ocean could not interact properly with biological diversity. Ecologically sensitive tourism is one of the important tourism with more advantages which includes less business owners and 
has very less disadvantages to the environmental resources as they are set up with local level accommodation. In this type of local level tourism, native culture is in high priority with avoidance of modern facilities with a motive to help in long-term development. As visitors are greatly involved in keeping the integrity of the protected areas, some visitors from adjoining nations are avoided to enter inside these areas (Vaughan, 2000).

More tourists have shown their interest towards natural resources conservation and they were also interested to pay more than the existing fee for the entry to the area. The most important thing about the low willingness to pay of visitor is the improper use of collected entry fee (Wrobel \& Kozlowski, 2011).

\section{Negative effects of tourism on the environment}

To start a tourism business, local people depend on scarce environmental resources, such as forests. Tourism can support a lot in developing economy and increase the construction activities in the local area. These types of development activities may also lead to exploitation of environmental resources which would be a win-win strategy (Varsi, 2012).

There is exploitation of environmental resources, and floral and faunal diversity for tourism promotion but the contribution of tourism to biodiversity and environmental services is minimal even in American sub-continents. There is high risk from tourism industry to the mangroves and corals of Caribbean coastal region which in turn is affecting habitat of important seafood species such as crab, shellfish, fish and lobsters in these areas. Large scale tourism industry consisting of hotels, resorts, water transport, and vocational home is affecting long term stability of tourism industry. Exploitation of shelter and food of wildlife and excessive fish farming from tourism related activities is depleting the stock of sea food. Due to this, these food items need to be imported from other part of the world to suffice local people and visitor's needs. Negative externalities had threatened the success of business as usual model by causing overuse of fresh water, improper management of solid waste and water, adverse impacts on coastal environment from excessive development works and overcrowding, high imports, and negative leakage of local economy. These external costs were reduced and sustainable economy was improved in tourism sector by sustainable ecosystem management (SEM) model. This model is brought into act to solve the problems arisen by BAU model as disturbance in tourism need to be solved sooner. Long term adverse impacts on local environment and tourism will shift the tourists towards other attractive destinations of the world (Bovarnick, et al., 2010).

Adverse impacts on coastal area and its ecosystem had increased motivation of the researcher to critically assess the adverse impact of business as usual approach 
of tourism. The current financial revenue from tourism will be short-term if the current approach is not discussed on timely manner. The competition of ecotourism in long run is directly linked to the wellness of the ecosystem. Environmental destruction and social and natural resources disruption will be promoted by short term vision on tourism which affects the sustainable growth of economy. Tourism in the case of Acapulco can be taken as an illustration for failure of BAU approach as there used to be large number of quality tourists in the area in the past. Huge growth of accommodation, rise in coastal pollution, noise pollution, improper waste management, air pollution, water pollution and drug usage had adversely affected this area as compared to past (Bovarnick, et al., 2010).

Despite the benefits of local scale ecotourism, there might be some problems towards flora and fauna, management of waste, and degradation of air, water and noise from different sources. Some of the adverse environmental impacts are already observed in high altitude regions and near the seas and the oceans (Vaughan, 2000).

\section{Economic benefits of ecotourism}

In some cases, local people having poor economic background get good benefits in spite of significant leakages. It occurs mostly in remote area which had limited income generating sources. In the case of rich households, they initiate tourism business by providing transport, lodging and fooding facilities (Narain \& Orfei, 2012).

One important strategy followed by state to reduce the adverse impact of people on parks is by setting buffer zones whose revenue from visitors is utilized in infrastructural development of the local community through local community forest users. These types of local forests with the involvement of communities are helping in income generation for the people through tourism activities. Also, various forest resources harvest near the national parks are used to prepare arts, crafts, hand-made items and gift items for the tourists. Various educational activities and research projects inside parks provide additional livelihood benefits to the people (Khatri, 2010).

In Nepal, tourism business could be one of the important sectors for generating national income. Tourism in Nepal was started from many decades in the past which was adversely affected by political instability and Maoist resurgence in between and again flourished after 2006 when Maoist problem was solved. These types of uncertainties and irregularities in business sectors had reduced transport and lodging related infrastructures throughout the country discouraging visitors to move from one place to the other for recreational activities. Different strategies were implemented by the state to enhance tourism sector, such as Visit Nepal and Nepal Tourism Year 2011 (Koirala, 2016).

Revenue received from ecotourism in Manaslu region had supported business activities as well as it had helped them to keep clean, green and healthy environment. 
Ecotourism had also supported the livelihood of local people through sale of their local product produced from plants and animals such as wooden arts and other souvenirs. The main important economic aspect of tourism is generation of local employment to earn money and to enhance the quality of life (K C \& Thapa Parajuli, 2014b).

It was observed that tourism projects planned in sensitive manner by combining participation and inclusion of poor and local people, focusing on ecological enhancement and development principles, bringing a direct market linkage had resulted in financial and overall advantages to the local region. It further provides motivation to conserve the natural resources and cultural heritage by interacting visitors, state agencies, tourism businesses and native communities (Kruk, 2009).

It was observed that some rural tourism models have failed while some have succeeded in getting financial benefits including money, job and grants for local societal projects. In the case of these types of tourism projects, different nations of South Africa are popular from previous two decades. Improvement in economy of poor and enhancement of living standard of people are the financial benefits that can be achieved from community based tourism projects (Mbaiwa \& Kolawole, 2013).

Poverty stricken and affected people dependent on agriculture, art, crafts and household industry inside the protected area who directly involve in protection of crop and other resources are indirectly supported by financial incentives from tourism activities. But the tourism business is unable to explore the full benefits of protection from local people and there is only some indirect support from tourism to local people (Hussain, et al., 2012).

\section{Negative impacts of tourism on economy}

Ecotourism projects provide financial advantages which are very less entertained by economically deprived local communities due to leakage of money (Narain \& Orfei, 2012). Also, promotion of tourism in a certain area increases economic inequality due to rise in local revenue from tourism and increase in overall price rates of the goods. Leakage of tourism benefits from business as usual approach underestimate the economic growth of the country. Also this approach affects the environment, ecological services, overall economy and the whole tourism sector in the long run. Large number of visitors in small area and small economy causes more rapid impacts as compared to large scale distribution of tourists in different places and cities of Southern region of American sub-continents (Bovarnick, et al., 2010).

\section{Tourism and its impact on culture}

Cultural heritage tourism had great scope in rural area which could be important source of attraction for the visitors to learn new ideas which in turn, develop tourism infrastructures in less developed areas of the country. This will not only promote 
tourism but also support the conservation of cultural heritage inside the country. Local indigenous societies could publicize their valuable cultures and traditions and also save their culture with the motivations from tourism revenues. But there is always a challenge for them to take tourism and cultural heritage conservation together for a long run (Koirala, 2016).

It was observed that entry of visitors to the park had caused significant improvement in social, economic and cultural aspects of local community. Few local people have experienced beneficial effects of tourism to the local communities, Tharu traditions and their income while some other observed the adverse impacts on these aspects. The negative aspects in Tharu culture were observed as the decrease in organization of festivals, Tharu feasts and their ceremonies whereas job availability was the positive aspect of it. Also, some respondents viewed medium transformations on traditions, society and the culture from tourism activities. The important thing is that tourism had led to higher level of involvement of the young people which make them to dishonor their elderly people, use drugs and alcohols, involve in crime and fights, and decrease the use of Tharu language and customs (Lipton \& Bhattarai, 2014).

\section{Conclusions}

Ecotourism had supported biodiversity conservation, socio-cultural development, and economic enhancement of local people. In many cases, benefits of ecotourism had outweighed the adverse impacts on the ecology, economy and society. Ecotourism and its positive impacts on biodiversity had also attracted more tourists. Diverse range of experts of ecotourism had conducted different methodologies for data collection, data analysis and presentation. Increase in number and species of plant and animal species had attracted more visitors and allure visitors to spend more money in other activities. It had further supported them to run projects for environmental conservation and help in socio-economic development. Increase in crime, quarrel and decrease in the use of local culture were few of the socio-cultural adverse impacts while encouragement in showing cultural heritage were the positive benefits. For long term development of ecotourism, priority should be given in community based tourism which allows a definite number of visitors. It can sustain the local culture and nature and help to increase income in the long run.

\section{References}

Bovarnick, A., Alpizar, F., \& Schnell, C. (2010). The importance of biodiversity and ecosystems in economic growth and equity in Latin America and the Caribbean: An economic valuation of ecosystems, , 2010: United Nations Development Programme.

Brandon, K., \& Margoluis, R. (1996). The ecotourism equation: measuring the impacts. In J. A. Miller (Ed.). New Haven: Yale University. 
Casey, F., Vickerman, S., Hummon, C., \& Taylor, B. (2006). Incentives for biodiversity conservation: An ecological and economic assessment. Washington DC: Defenders of Wildlife.

Hussain, S. A., Barthwal, S. C., Badola, R., Rahman, S. M. T., Rastogi, A., Tuboi, C., \& Bhardwaj, A. K. (2012). An analysis of livelihood linkages of tourism in Kaziranga National park, A natural world heritage site in India. Parks, 18(2), 3343.

K C, A. (2016). Hydropower development, ecotourism and green economy in the context of Nepal. Bidhyut, 26(2), 9-13.

K C, A. (2017a). Climate change and its impact on tourism in Nepal. Journal of Tourism and Hospitality Education, 7, 25-43.

K C, A. (2017b). Community forestry management and its role in biodiversity conservation in Nepal. In L. G. A. Stephen (Ed.), Wildlife Research (Vol. 1, pp. 51-72). Kathmandu: InTech.

K C, A. (2017c). Ecotourism in Nepal. The Gaze: Journal of Tourism and Hospitality, $8(1), 1-19$.

K C, A., \& Ghimire, A. (2015). High-altitude plants in era of climate change: A case of Nepal Himalayas. In M. Ozturk, K. R. Hakeem, I. Faridah-Hanum \& R. Efe (Eds.), Climate change impacts on high-altitude ecosystems (Vol. 1, pp. 177-189). Switzerland: Springer International Publishing.

K C, A., Joshi, G. R., \& Aryal, S. (2014). Opportunity cost, willingness to pay and cost benefit analysis of a community forest of Nepal. International Journal of Environment, 3(2), 108-124.

K C, A., Rijal, K., \& Sapkota, R. P. (2015). Role of ecotourism in environmental conservation and socioeconomic development in Annapurna conservation area, Nepal. International Journal of Sustainable Development \& World Ecology, 22(3), 251-258.

K C, A., \& Thapa Parajuli, R. B. (2014a). Climate change and its impact on tourism in the Manaslu conservation area, Nepal. Tourism Planning \& Development, 225237.

K C, A., \& Thapa Parajuli, R. B. (2014b). Tourism and its impact on livelihood in Manaslu conservation area, Nepal. Environment Development and Sustainability, $16,1053-1063$.

K. C., A. (2016). Ecotourism and Its Role in Sustainable Development of Nepal. In L. Butowski (Ed.), Tourism - From Empirical Research Towards Practical Application (pp. 31-59): In Tech. 
Kaffashi, S., Radam, A., Shamsudin, M. N., Yacob, M. R., Nordin:, H., \& Nordin, N. H. (2015). Ecological conservation, ecotourism, and sustainable management: The case of Penang national park. Forests, 6, 2345-2370. doi: 10.3390/f6072345

Khatri, T. B. (2010). Conservation governance in Nepal: protecting forest biodiversity and people's livelihoods. Unasylva 236, 61, 34-40.

Koirala, I. (2016). Indigenous cultural tourism in Chitwan, Nepal: obtaining sustainability in Tharu culture and tourism. Master, UiT the Arctic University of Norway, Alta.

Kruk, E. (2009, 15-22 June 2009). Tourism and sustainable mountain development in the Hindu Kush-Himalayas. Paper presented at the Integrated tourism concepts to contribute to sustainable mountain development in Nepal, Nepal.

Lipton, J. K., \& Bhattarai, U. (2014). Park establishment, tourism, and livelihood changes: A case study of the establishment of Chitwan National Park and the Tharu people of Nepal. American International Journal of Social Science, 3(1).

Makindi, S. M. (2016). Local communities, biodiversity conservation and ecotourism: a case study of the Kimana Community Wildlife Sanctuary, Kenya. African Journal of Hospitality, Tourism and Leisure, Special edition 5(3).

Mbaiwa, J. E., \& Kolawole, O. D. (2013). Tourism and biodiversity conservation: the case of community-based natural resource management in Southern Africa. $C A B$ Reviews, 8(10), 1-10.

Mellor, J. W. (2002). Poverty reduction and biodiversity conservation: The complex role for intensifying agriculture Poverty and the environment. Washington DC: WWF Macroeconomics Program Office.

Narain, U., \& Orfei, A. (2012). Biodiversity, nature-based tourism, and jobs. Washington DC: The World Bank.

Nyaupane, G. P., \& Poudel, S. (2011). Linkages among biodiversity, livelihood, and tourism. Annals of Tourism Research, 38(4), 1344-1366. doi: 10.1016/j. annals.2011.03.006

Regmi, N. (2016). Rural tourism in Nepal: Development and sustainability, A case study of Parbat District, Nepal. Bachelor, Centria University of Applied Sciences, FInland.

TMI. (2000). Community based tourism for conservation and development: A resource kit. Washington DC, USA: The Mountain Institute.

Varsi, R.-A. (2012). Imagined biodiversity through conservation-as-development, tracing more than a decade with natural co-management in Shey Phoksumdo National Park in Nepal. Master in Social Anthropology, University of Oslo, Oslo. 
Vaughan, D. (2000). Tourism and biodiversity: A convergence of interests. International Affairs, 76(2), 283-297.

Wrobel, C., \& Kozlowski, A. (2011). Tourists' willingness to pay for entry to the Annapurna Conservation Area, Nepal. Himalayan Journal of Development and Democracy, Vol. 6, No. 1, 2011, 6(1). 